\title{
청피의 항염증효과
}

\author{
예영준 · 김연섭 · 강미숙 ${ }^{1}$
}

가천대학교 한의과대학 해부경혈학교실, ${ }^{1}$ 침구의학교실

\section{Effects of Citri Reticulatae Viride Pericarpium on 4-Hydroxynonenal-Induced Inflammation in PC12 Cells}

\author{
Young Jun Ye, Youn Sub Kim, Mi Suk Kang ${ }^{1}$ \\ Departments of Anatomy-Pointology and ${ }^{1}$ Acupuncture and Moxibustion, College of Korean Medicine, Gachon University
}

Received: October 7, 2016 Revised: December 13, 2016 Accepted: December 13, 2016

\author{
Correspondence to: Mi Suk Kang \\ Department of Acupuncture and \\ Moxibustion, College of Korean \\ Medicine, Gachon University, 1342 \\ Seongnam-daero, Seongnam 13120, \\ Korea \\ Tel: +82-32-770-1342 \\ Fax: +82-32-468-4033 \\ E-mail: cyberdoc001@hanmail.net \\ Copyright $@ 2016$ by The Society of Korean \\ Medicine for Obesity Research
}

\begin{abstract}
Objectives: The purpose of this study was to observe the effects of Citri Reticulatae Viride Pericarpium (CP) on 4-Hydroxynonenal (4-HNE)-induced inflammation in PC12 cells.

Methods: 4-HNE was treated in PC12 cell to cause inflammatory response, and then treated with $\mathrm{CP}$ water extract at 25,50 , and $100 \mu \mathrm{g} / \mathrm{ml}$. The phosphorylation of Jun $\mathrm{N}$-terminal kinase (JNK) and the expression of NF- $\mathrm{kB}$ in PC12 cells were determined by Western blot, respectively.

Results: The phosphorylation of JNK was significantly decreased in 4-HNE-stimulated PC12 cell by the treatment of CP extract at $25 \mu \mathrm{g} / \mathrm{ml}$. The $4-\mathrm{HNE}$-induced expression of nuclear factor kappa-light-chain-enhancer of activated $\mathrm{B}$ cells (NF-kB) p65 in nuclear of the cells was significantly decreased in PC12 cell by treatment with CP extract at 25,50 , and $100 \mu \mathrm{g} / \mathrm{ml}$.

Conclusions: These results suggest that $\mathrm{CP}$ water extract has an anti-inflammatory activity through suppressing the JNK and NF-kB activation.
\end{abstract}

Key Words: Citri Reticulatae Viride Pericarpium, 4-HNE, pJNK, pNF-кB

\section{서 론}

염증(inflammation)은 상해를 방어하며, 사멸되고 손상 된 세포를 없애고, 스트레스, 부상 및 감염에 의한 손상 지 역을 정상 상태로 되돌리려는 복잡한 세포 및 분자들의 반 응으로 ${ }^{1)}$ 적절한 염증반응은 인체를 보호하는 데 필수적이나 과도하거나 부적절한 염증반응은 만성으로 진행되어 알츠 하이머병, 파킨슨병, 다발성 경화증, 뇌종양 및 수막염을 비 롯한 다양한 퇴행성 신경질환의 발달에 중요한 역할을 한달. 4-Hydroxynonenal (4-HNE)은 오메가6 불포화 지방산의 과산화반응으로 세포막 지질 과산화에 의해 생성되는 알데 히드의 하나로 ${ }^{3)}$ 높은 농도의 4-HNE은 PC12 세포에서 Jun N-terminal kinase (JNK)를 활성화시키고 ${ }^{4}$, nuclear factor kappa-light-chain-enhancer of activated B cells
$(\mathrm{NF}-\kappa \mathrm{B})$ 의 인산화를 증가시켜 염증성 사이토카인 상승과 같은 강한 염증작용을 일으킨다 ${ }^{5)}$. 또한 세포막과 관련된 포 도당과 글루타민산염 수송체, 이온이동 ATPase, 아밀로이 드의 대사에 관여하는 효소 및 세포골격 단백질의 변화에 의해 비만, 당뇨병, 대사증후군 및 파킨슨병, 알츠하이머병 과 같은 신경 퇴행성 질환 등 다양한 질병의 원인이 된당. 최근에는 Purkayastha와 $\mathrm{Cai}^{7}{ }^{7}$ 가 염증 신호의 활성화와 비 만증에 관한 연구, $\mathrm{Ham}^{8}$ 의 비만과 염증반응 및 산화스트 레스에 관한 연구, $\mathrm{Cho}^{9}$ 의 운동이 비만 중년 여성의 염증 지표에 미치는 영향 등의 연구를 통해 비만과 염증과의 관 계에 대한 다양한 접근이 활발하게 이루어지고 있는 실정이 다.

靑皮 (Citri Reticulatae Viride Pericarpium, CP)는 芸香科 (Rutaceae)에 속한 상록 소교목인 귤나무(reticulata Blanco) 
의 유목 또는 미성숙 과실의 과피를 건조한 것으로 疏肝破 氣, 散結消痰, 胸脇胃脘疼通을 치료하는 데 사용된다 ${ }^{10)}$. 靑皮의 주요성분은 hesperidin이고 narirutin과 hesperetin 도 상당량 함유하고 있으며 ${ }^{11)}$ 약리학적으로 靑皮는 $\alpha$, $\alpha$-diphenyl- $\beta$-picrylhydrazyl (DPPH) free radical-scavenging 활성을 이용한 항산화 작용 ${ }^{12,13)}$ 외에 허혈성 모델 쥐에서의 뇌 보호 ${ }^{14)}$, compound $48 / 80$ 로 유발된 모델 쥐에서 항알레 르기 ${ }^{15)}$ 및 천식 마우스 모델에서 천식 억제 ${ }^{16)}$, 마우스 면역 세포에서 면역조절기능 ${ }^{17)}$ 등이 있는 것으로 보고되고 있다. 이러한 효능들로 보아, 靑皮가 4-HNE에 손상된 신경세포 에 대해 보호 작용이 있을 것이라 생각되어 염증반응 시 염 증매개물 생성을 유도하는 염증신호전달분자인 JNK와 전 사인자인 NF- $\mathrm{KB}$ 의 활성화 기전에 대한 억제효과를 확인하 였다.

\section{재료 및 방법}

\section{1. 세포배양}

본 실험에 사용한 PC12 세포는 신경세포의 특성을 나타 내는 rat adrenal pheochromocytoma cell line으로 한국세 포주은행(KCLB, Seoul, Korea)에서 구입하였다. 세포배양 을 위해 10\% horse serum, 5\% fetal bovine serum, $1 \%$ penicillin/streptomycin, $2 \% \mathrm{NaHCO}_{3}$ 가 포함된 RPMI1640 배지를 배양액으로 사용하였으며 $37^{\circ} \mathrm{C}$ 의 온도와 $5 \%$ $\mathrm{CO}_{2}$ 가 포함된 공기가 공급되는 $\mathrm{CO}_{2}$ incubator에서 배양 하였다.

\section{2. 기기 및 시약}

\section{1) 기기}

본 실험을 위해 사용된 기기로는 Clean Bench (Nuaire, Plymouth, MN, USA), $\mathrm{CO}_{2}$ Incubator (Nuaire), Spectrophotometer (Implen, München, Germany), Water Purification (High-Q, Wilmette, IL, USA), Microplate Reader (Dynex, Chantilly, VA, USA), Freezing dryer (Eyela, Tokyo, Japan), Sonicator (Sonics, Newto, CT, USA), Auto clave (Sam Woo, Gimpo, Korea), Balance (Mettler, Greifensee, Switzerland), Automatic X-ray Filmprocessor
(JPI, Seoul, Korea), Centrifuge (Hanil, Suwon, Korea) 등 이 있다.

\section{2) 시약}

본 실험에 사용된 시약으로는 4-HNE (Cayman, Ann abor, MI, USA), MTT (Sigma-Aldrich, St. Louis, MO, USA), RPMI Medium 1640 (Gibco; Thermo Fisher Scientific, Waltham, MA, USA), fetal bovine serum (Gibco; Thermo Fisher Scientific), Horse Serum (Gibco; Thermo Fisher Scientific), Sodium Bicarbonate (SigmaAldrich), Sodium Chloride (Sigma-Aldrich), Dimethyl Sulfoxide (Amresco, Solon, OH, USA), Trzma Base (Sigma-Aldrich) 등을 구입하여 사용하였다.

\section{3. 약물 제조}

본 실험에 사용한 靑皮 (CP) (주)옴니허브(Daegu, Korea) 에서 구입하였다. 추출물 제조를 위해 증류수 $500 \mathrm{ml}$ 에 검 皮 $50 \mathrm{~g}$ 을 환류추출기에 넣고 2시간 동안 전탕하였으며, 그 여과액을 rotary evaporator로 감압 농축한 후 $-85^{\circ} \mathrm{C}$ 에서 동결건조하였다. 이때 얻어진 靑皮 물추출물 $(\mathrm{CP})$ 은 $7 \mathrm{~g}$ 으 로 수율은 $14 \%$ 였다.

\section{4. 단백질 발현 분석(Western blot analysis)}

$\mathrm{PC} 12$ 세포는 $100 \mathrm{~mm}$ dish에 $5 \times 10^{6}$ 개씩 분주하고 4-HNE $(35 \mu \mathrm{mol})$ 과 CP $(25,50,100 \mu \mathrm{g} / \mathrm{ml})$ 를 처리하여 24시간 배양하였다. 세포를 수거한 후 $1 \times$ phosphate buffer saline (pH 7.4)으로 2번 씻어낸 후 1,000 rpm에서 10 분 동안 원심 분리하였다. 세포침전물에 세포분해용액 (iNtRON Biotechnology, Seongnam, Korea)을 넣은 후 초음파 분쇄기로 세포를 균질화하고 다시 20 분 동안 $12,000 \mathrm{rpm}$ 으로 원심 분리하였다. 단백질 정량은 protein assay dye reagent (Bio-Rad, Hercules, CA, USA)를 사용 하여 흡광도를 측정하였다. 정량한 단백질을 $\mathrm{Mini}-$ PROTEAN $^{\circledR} \mathrm{TGX}^{\mathrm{TM}} \mathrm{Gel}$ (Bio-Rad)에 loading하여 분리 한 다음 $4^{\circ} \mathrm{C}$ 냉장고 안에서 nitrocellulose membrane (NC; $\mathrm{Bio}-\mathrm{Rad}$ )으로 이동시켰다. NC membrane에 1차 항체인 mouse anti-actin antibody (Merck Millipore, Billerica, $\mathrm{MA}$, USA)와 rabbit anti-JNK antibody (CST, Danvers, 
MA, USA), rabbit anti-pJNK antibody (CST), rabbit anti-NF- $\mathrm{\kappa B}$ p65 antibody (CST) 및 rabbit anti-pNF$\kappa \mathrm{B}$ p65 antibody (CST)와 $4^{\circ} \mathrm{C}$ 에서 overnight 반응시키고, 3 회 세척한 후 2차 항체로서 actin은 mouse immunoglobulin $G$ horseradish peroxidase-conjugated antibody (R\&D Systems, Inc., Minneapolis, MN, USA)와 JNK, phosphorylation of JNK (pJNK), NF- $\mathrm{BB}$ p65, pNF- $\mathrm{kB}$ p65 는 horseradish peroxidase-conjugated anti-rabbit antibody (CST)를 사용하여 실온에서 1시간 반응시켰다. 단백질 밴 드의 검출은 clarity western ECL substrate (Bio-Rad)를 사용하여 발색시킨 후 X-ray film으로 감광시켜 이미지화 한 후 이를 이미지 프로그램(ImageJ)을 사용하여 정량하였 다.

\section{5. 통계처리}

통계분석은 4-HNE와 4-HNE+靑皮 투여 group 간의 유의성 검증을 위해 GraphPad Prism ver. 3 (GraphPad Software, Inc., La Jolla, CA, USA)으로 Student's t-test를 사용하였으며, 실험 결과는 평균 \pm 평균의 표준오차로 나타 냈다. 통계적 유의성 검정은 $\mathrm{P}<0.05$ 로 하였다.

\section{결 과}

\section{1. 青皮추출물의 pJNK 단백질 발현에 대한 효과}

세포 외 염증자극을 세포막에서 세포 내 핵까지 전달하 는 신호전달분자 중 하나인 JNK MAPK 발현 조절에 대한 靑皮의 효과를 관찰하고자 PC12 세포에 곅皮추출물을 처 리하고 염증유도물질인 4-HNE를 처리한 후 JNK의 인산 화 단백질 $(\mathrm{pJNK})$ 의 발현을 Western blot으로 측정하였다.

그 결과, 정상군(normal)에서의 $\mathrm{pJNK}$ 단백질 발현량을 $100 \%$ 로 하였을 때 4-HNE만 처리한 대조군(control)의 발 현은 200.9\% $\pm 16.73 \%$ 로 나타났다. 또한 靑皮추출물(CP) 을 $25 \mu \mathrm{g}$ 과 4-HNE를 처리한 $\mathrm{CP} 25$ 군에서 $\mathrm{pJNK}$ 의 발현이 $148.3 \% \pm 8.79 \%$ 로 나타났고, $50 \mu \mathrm{g}$ 과 4- $\mathrm{HNE}$ 를 처리한 $\mathrm{CP} 50$ 군에서 $145.2 \% \pm 23.91 \%$, 靑皮추출물 $100 \mu \mathrm{g}$ 과 4-HNE를 처리한 CP100군에서 $162.6 \% \pm 30.00 \%$ 로 모두 대조군에 비해 감소하였으며, $\mathrm{CP} 25$ 군에서 유의성 있는 감 소가 관찰되었다(Fig. 1).

\section{2. 靑皮추출물의 $p N F-\kappa B$ p65 단백질 발현에 대한 효과}

靑皮추출물의 염증전사인자 중 하나인 NF- $\mathrm{kB}$ p65에 대 한 억제효과를 확인하고자 PC12 세포에 靑皮추출물(CP)을 투여하고 4-HNE를 처리한 다음 세포질 내의 $\mathrm{pNF}-\kappa \mathrm{B}$ p65 단백질 발현을 Western blot으로 확인하였다.

그 결과 정상군(normal)에서의 $\mathrm{pNF}-\kappa \mathrm{B}$ p65 단백질 발 현을 $100 \%$ 로 하였을 때, 4-HNE만 처리한 대조군의

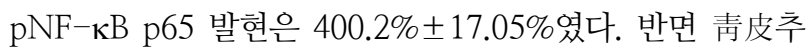
출물 $25 \mu \mathrm{g}$ 과 4- $\mathrm{HNE}$ 를 처리한 $\mathrm{CP} 25$ 군에서 $\mathrm{pNF}-\kappa \mathrm{B}$ p65 단백질 발현은 $181.7 \% \pm 57.24 \%$, 靑皮추출물 $50 \mu \mathrm{g}$ 과 4-HNE를 처리한 CP50군에서는 $156.0 \% \pm 60.13 \%$, 靑皮 추출물 $100 \mu \mathrm{g}$ 과 4-HNE를 처리한 $\mathrm{CP} 100$ 군에서는 $165.9 \% \pm$ $50.91 \%$ 로 모두 대조군에 비해 유의한 감소 효과를 나타내 었다(Fig. 2).
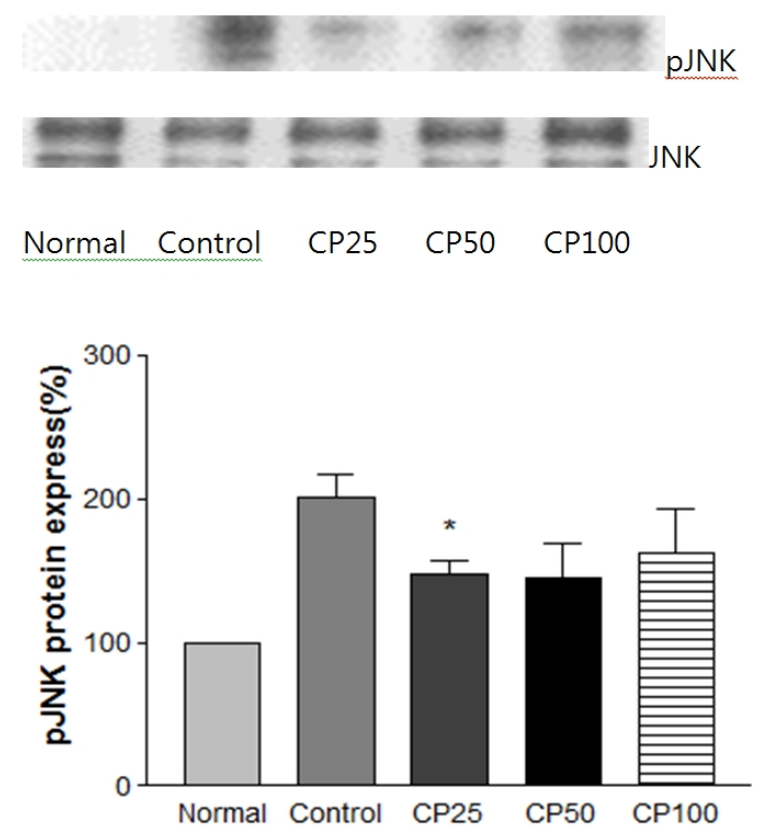

Fig. 1. Effect of CP on pJNK expression. Data are represented by mean \pm standard error of mean ( $n=4$ in each group). CP: Citri Reticulatae Viride Pericarpium, pJNK: phosphorylation of Jun N-terminal kinase, JNK: Jun N-terminal kinase, Normal: only media-treated group, Control: $35 \mu \mathrm{mol} 4$ 4-Hydroxynonenal (4-HNE)-treated group, CP25: $35 \mu \mathrm{mol} 4-\mathrm{HNE}$ and $25 \mu \mathrm{g} / \mathrm{ml} \mathrm{CP}$-treated group, CP50: $35 \mu \mathrm{mol}$ 4-HNE and $50 \mu \mathrm{g} / \mathrm{ml} \mathrm{CP-treated} \mathrm{group,} \mathrm{CP100:} 35 \mu \mathrm{mol} 4-\mathrm{HNE}$ and $100 \mu \mathrm{g} / \mathrm{ml}$ CP-treated group. Statistical significances are based on comparison to the control group ( $\left.{ }^{*} \mathrm{P}<0.05\right)$. 


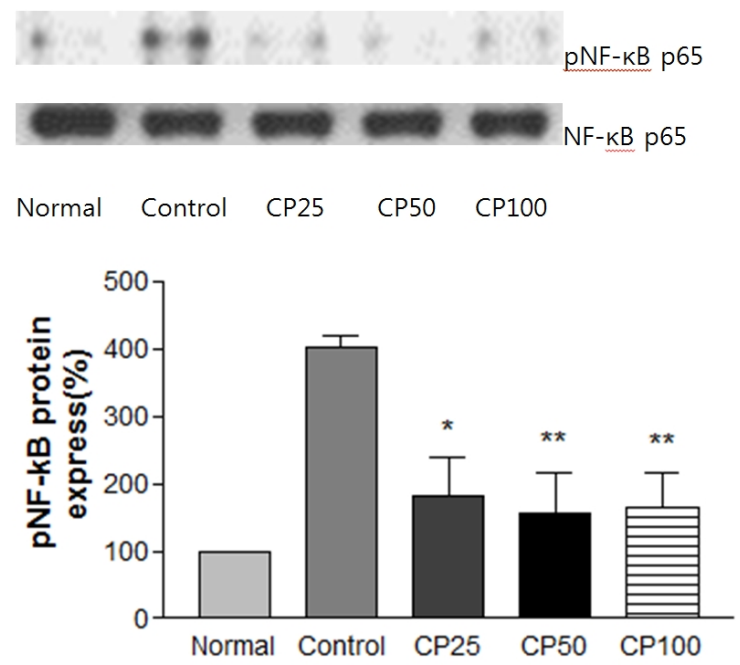

Fig. 2. Effect of CP on pNF-кB expression. Data are represented by mean \pm standard error of mean ( $n=4$ in each group). CP: Citri Reticulatae Viride Pericarpium, pNF-кB: phospho-nuclear factor kappa-lightchain-enhancer of activated B cells, NF-к: nuclear factor kappa-lightchain-enhancer of activated B cells, Normal: only media- treated group, Control: $35 \mu \mathrm{mol}$ 4-Hydroxynonenal (4-HNE)-treated group, CP25: $35 \mu \mathrm{mol} 4-\mathrm{HNE}$ and $25 \mu \mathrm{g} / \mathrm{ml}$ CP-treated group, CP50: 35 $\mu \mathrm{mol} 4-\mathrm{HNE}$ and $50 \mu \mathrm{g} / \mathrm{ml}$ CP-treated group, CP100: $35 \mu \mathrm{mol}$ 4-HNE and $100 \mu \mathrm{g} / \mathrm{ml}$ CP-treated group. Statistical significances are based on comparison to the control group $\left({ }^{*} \mathrm{P}<0.05\right.$; $\left.{ }^{* \star} \mathrm{P}<0.01\right)$.

\section{고 찰}

靑皮는 性味가 苦辛하고 溫하여 辛味는 發散하고 溫性 은 通氣시키며 苦味는 泄氣시켜 하행하게 하여 肝 膽二經 에 들어가 肝氣鬱滯로 인한 脇肋脹痛과 乳房脹痛 및 疝氣 疼通 등을 치료하는데 효과가 있다 ${ }^{10)}$.

비만과 진피에 관한 연구는 여러 방면에서 이루어지고 있는데 ${ }^{18,19)}, \mathrm{Choi}^{20)}$ 는 청피와 진피가 항비만 소재로 사용될 수 있음을 말하였다. 청피에 관한 기존연구로는 $\mathrm{Joo}^{21}$ 는 청 피가 PC12 신경세포에서 4-HNE에 의한 세포사멸에 항산 화 효과가 있음을 또한 염증반응은 산화 스트레스의 증가와 관련이 있다는 연구도 있었다 ${ }^{22)}$. 이에 저자는 靑皮를 이용 하여 세포손상에 의한 염증반응에 어떤 영향을 미치는 지를 연구하기 위해 PC12 세포에 靑皮추출물을 투여하 고 4-HNE를 처리한 다음 염증반응에 관여하는 대표적 인 인자인 $J N K$ 와 $N F-\kappa B$ 인산화 단백질 발현량을 관찰 하기 위해 Western blot을 실시하였다.

PC12 세포는 신경세포의 특성을 가지고 있어 세포사멸 과 항산화효능 실험이 일반적이지만 과산화와 염증은 밀접
한 관계가 있어 PC12 세포로 염증인자를 볼 수 있달) MAPKS는 세포외부의 자극을 세포막에서부터 세포핵까지 전달하는 대표적인 신호전달 경로로 extracellular signalactivated kinases, JNK, p38 MAPK 세 가지로 분류되며 ${ }^{24)}$ 염증성 매개 물질의 생성에 관여하는 중요한 신호 전달 경 로이기도 하다 ${ }^{25)}$. 이 중 $\mathrm{JNK}$ 는 세포외부의 스트레스성 자 극에 의해 활성화되며 염증반응을 매개하는 것으로 알려져 있다 ${ }^{26)}$.

따라서 본 실험은 PC12 세포에서 $\mathrm{pJNK}$ 단백질 발현을 Western blot을 통해 관찰한 결과, 궥皮추출물 $25 \mu \mathrm{g}, 50$ $\mu \mathrm{g}$ 및 $100 \mu \mathrm{g}$ 을 투여한 모든 군은 대조군에 비해 감소하였 으며, $25 \mu \mathrm{g}$ 을 투여한 군에서는 유의성이 있는 감소가 관찰 되었다.

$\mathrm{NF}-\kappa \mathrm{B}$ 는 염증조절의 중요한 인자로 NF- $\mathrm{\kappa B} 1$ (p50/ p105), NF- $\kappa$ B2 (p52/p100), RELA (p65), C-REL 및 $\mathrm{RelB}$ 와 같은 5 개의 소단위체로 구성되어 있으며 면역과 염 증반응 및 세포증식과 세포사멸을 조절한다 ${ }^{5)} . \mathrm{NF}-\kappa \mathrm{B}$ 계열 중 가장 일반적이고 특성화된 형태인 P50/P65는 자극이 없 는 상태에서 억제 단백질인 inhibitor kappa-B (IкB)와 결 합하여 보통 세포질에서 비활성 이종이량체로 존재한다. 그 러나 염증반응과 같은 세포의 자극에 반응하여 IкB kinase 가 활성화된 후 인산화 과정을 통해 IKB는 분리되고, 자유 롭게 된 $\mathrm{NF}-\kappa \mathrm{B}$ 염증성 매개 물질의 전사를 조절하는 표적 유전자의 promoter에 결합하게 된다 ${ }^{27)}$. 또한 $\mathrm{pNF}-\mathrm{\kappa B}$ 역 시 염증반응의 마커로 확인하기도 하지만 핵안으로 $\mathrm{NF}-\kappa \mathrm{B}$ 의 이동을 확인하는 지표로 사용된다.

따라서 본 실험은 $\mathrm{PC} 12$ 세포에서 $\mathrm{pNF}-\kappa \mathrm{B}$ p65 단백 질 발현을 Western blot을 통해 관찰한 결과, 靑皮추출 물 $25 \mu \mathrm{g}, 50 \mu \mathrm{g}$ 및 $100 \mu \mathrm{g}$ 투여한 모든 군은 대조군에 비해 유의성 있는 감소를 나타내었다.

이상의 결과들을 종합해보면 곡皮는 항염증과 관련된 $J N K$ 와 $N F-\kappa B$ 의 인산화를 억제하였다.

\section{결 론}

靑皮가 신경세포에서 항염증 작용을 나타내는지 확인하 기 위하여 PC12 세포에 4-HNE을 처리하여 염증반응을 유도한 후 염증신호전달분자인 JNK와 전사인자인 NF- $\mathrm{KB}$ 
인산화 단백질 발현을 관찰하여 아래와 같은 결과를 얻었다

1. pJNK 단백질 발현량은 靑皮 물추출물 $25 \mu \mathrm{g} / \mathrm{ml}$ 투여 군에서 대조군에 비해 유의성 있는 감소를 나타냈다.

2. $\mathrm{pNF}-\kappa \mathrm{B}$ p65 단백질 발현량은 靑皮 물추출물 25,50 및 $100 \mu \mathrm{g} / \mathrm{ml}$ 투여군에서 대조군에 비해 유의성 있는 감소 를 나타냈다.

이상의 결과로 보아, 靑皮 물추출물은 신경세포에서 JNK 와 NF- $\mathrm{KB}$ 의 활성화를 억제하여 항염증효과를 나타냈다.

\section{References}

1. Whitney NP, Eidem TM, Peng H, Huang Y, Zheng JC. Inflammation mediates varying effects in neurogenesis: relevance to the pathogenesis of brain injury and neurodegenerative disorders. J Neurochem. 2009 ; 108(6) : 1343-59.

2. Kannappan R, Gupta SC, Kim JH, Reuter S, Aggarwal BB. Neuroprotection by spice-derived nutraceuticals: you are what you eat! Mol Neurobiol. 2011 ; 44(2) : 142-59.

3. Siddiqui MA, Kumar V, Kashyap MP, Agarwal M, Singh AK, Khanna VK, et al. Short-term exposure of 4-hydroxynonenal induces mitochondria-mediated apoptosis in PC12 cells. Hum Exp Toxicol. $2012 ; 31(4): 336-45$.

4. Bruckner SR, Estus S. JNK3 contributes to c-jun induction and apoptosis in 4-hydroxynonenal-treated sympathetic neurons. J Neurosci Res. 2002 ; 70(5) : 665-70.

5. Yin G, Wang Y, Cen XM, Yang M, Liang Y, Xie QB. Lipid peroxidation-mediated inflammation promotes cell apoptosis through activation of NF- $\mathrm{KB}$ pathway in rheumatoid arthritis synovial cells. Mediators Inflamm. 2015 : 460310.

6. Mattson MP. Roles of the lipid peroxidation product 4-hydroxynonenal in obesity, the metabolic syndrome, and associated vascular and neurodegenerative disorders. Exp Gerontol. 2009; 44(10) : 625-33.

7. Purkayastha S, Cai D. Disruption of neurogenesis by hypothalamic inflammation in obesity or aging. Rev Endocr Metab Disord. 2013 ; 14(4) : 351-6.

8. Ham MR. Role of macrophage glucose-6-phosphate dehydrogenase in proinflammatory responses and oxidative stress associated with obesity. Doctor thesis. Seoul: Seoul University. 2013.

9. Cho WJ. Effects of combined and walking exercises on inflammatory markers in obese middle-aged women. Korea J Sport. $2013 ; 11(1): 251-63$.

10. Oriental University Edit Committee. Herbology. Seoul : YoungLim Co. $2011: 217$.

11. Baik SO, Bock JY, Chun HJ, Jeong SI, Baek SH, Oh HB, et al.
Analysis and quantitative distribution of glycosided flavonoids in citruses and Korean Chung-pi. Anal Sci Technol. $2001 ; 14(4)$ : 340-8.

12. Min SS, Yuan TS, Po JC. Antioxidant activities of citrus herbal product extracts. Food Chem. 2008 ; 111 : 892-6.

13. Li X, Huang Y, Chen D. Protective effect against hydroxylinduced DNA damage and antioxidant activity of citri reticulatae pericarpium. Adv Pharm Bull. 2013 ; 3(1) : 175-81.

14. Rho YH, Jeong HW, Lee WS. Experimental study of fraction of Citri Reticulatae Viride Pericarpium extract on the brain damage in cerebral ischemia. Korean J Orient Physiol Pathol. $2002 ; 16: 893-8$.

15. Kim DK, Lee KT, Eun JS, Zee OP, Lim JP, Eum SS, et al. Anti-allergic components from the peels of Citrus unshiu. Arch Pharm Res. 1999 ; 22(6) : 642-5.

16. Lee HJ. Effects of citro reticulatae viride pericarpium on the vascular endothelial growth factor (VEGF) in the bronchial asthma mouse model. J Pediatr Korean Med. 2006 ; 4 : 181-94.

17. Jeong $\mathrm{HY}$, Oh CH, Eun JS. Effect of Citri Reticulatae Viride Pericarpium water extract on immunocytes in mice. Korean J Orient Med Pathol. 1998 ; 12 : 55-62.

18. Jung SY. Anti-obesity effect of Citrus unshiu peel in rats fed a high-fat diet. Master thesis. Seoul: Kyunghee University. 2013.

19. Jo HK, Han MH, Hong SH, Choi YH, Park C. Ethanol extracts of citrus peel inhibits adipogenesis through AMPK signaling pathway in 3T3-L1 preadipocytes. J Life Sci. 2015 ; 25(3) : 285-92.

20. Choi ES. Effect of citri unshiu pericarpium and citri unshiu pericarpium immaturus on differentiation of pre-adipocyte. Master thesis. Iksan: Wonkwang University. 2014.

21. Joo KG. Effects of Citri Reticulatae Viride Pericarpium on apoptosis in PC-12 cell. Master thesis. Seongnam: Gachon University. 2016.

22. Xie QW, Kashiwabara Y, Nathan C. Role of transcription factor NF-kappa B/Rel in induction of nitric oxide synthase. J Biol Chem. $1994 ; 269(7)$ : 4705-8.

23. Fu J, Shi Q, Song X, Xia X, Su C, Liu Z, et al. Tetrachlorobenzoquinone exhibits neurotoxicity by inducing inflammatory responses through ROS-mediated IKK/IKB/NF- $\mathrm{B}$ signaling. Environ Toxicol Pharmacol. $2016 ; 6$ : 241-50.

24. Yoon JH, Youn K, Ho CT, Karwe MV, Jeong WS, Jun M. P coumaric acid and ursolic acid from corni fructus attenuated $\beta$ amyloid25-35-induced toxicity through regulation of the NF-kB signaling pathway in PC12 cells. J Agric Food Chem. 2014 ; 62(21) : 4911-6.

25. Kang SY, Jung HW, Lee MY, Lee HW, Chae SW, Park YK. Effect of the semen extract of Cuscuta chinensis on inflammatory responses in LPS-stimulated BV-2 microglia. Chin J Nat Med. $2014 ; 12(8): 573-81$. 
26. Caivano M. Role of MAP kinase cascades in inducing arginine transporters and nitric oxide synthetase in RAW264 macrophages. FEBS Lett. 1998 ; 429(3) : 249-53.
27. Nolan GP, Ghosh S, Liou HC, Tempst P, Baltimore D. DNA binding and $\mathrm{I} \kappa \mathrm{B}$ inhibition of the cloned $\mathrm{p} 65$ subunit of NF- $\kappa \mathrm{B}$, a rel-related polypeptide. Cell. 1991 ; 64(5) : 961-9. 